\title{
KOMUNIKASI PEMASARAN TERPADU DAN EKUITAS MEREK ALFAMART
}

\author{
Jehuda Ghrahito Hutomo Krussell ${ }^{1}$ dan Eristia Lidia Paramita² \\ Fakultas Ekonomika dan Bisnis, Universitas Kristen Satya Wacana Salatiga \\ J1. Diponegoro No. 52-60 Salatiga 50711, Jawa Tengah (0298) 311881 \\ Email:jehudaghk@gmail.com¹ dan eristia.paramita@staff.uksw.edu²
}

\begin{abstract}
In past few years, retail business has significantly improved. Company needs marketing strategy to raise their competitiveness and make a good brand equity. One of these strategy that can be used is Integrated Marketing Communication. This study aimed to examine the influence of integrated marketing communication toward brand equity. This study was a quantitative study. The sample of 150 respondents were taken by using purposive sampling. The data analysis used multiple linear regression. These findings showed that dimension of integrated marketing communication consists of Advertising, Sales Promotion, Personal Selling, Public Relation, Direct Marketing, Interactive Marketing, and Corporate Design together influence Alfamart Brand Equity. While partially, only Sales Promotion, Personal Selling, and Corporate Design has significantly influence Alfamart Brand Equity.
\end{abstract}

Keywords: Integrated Marketing Communication, Brand Equity, Retail Business, Alfamart

\section{PENDAHULUAN}

Persaingan bisnis di Indonesia saat ini sudah semakin pesat. Salah satu bisnis yang semakin berkembang di Indonesia adalah dari sektor perdagangan. Pertumbuhan ini tidak lepas dari berkembangnya bisnis ritel yang ada di Indonesia. Berdasarkan survey yang dilakukan Asosiasi Pengusaha Ritel Indonesia (Aprindo) pada tahun 2015, perkembangan bisnis ritel di tahun 2015 mengalami peningkatan sebesar $12 \%$, dibandingkan pada tahun 2014. Menurut data Indeks Pembangunan Ritel Global (GRDI) yang diunggah At Kearney pada tahun 2015, posisi perkembangan ritel Indonesia berada di peringkat 12 dunia. Ini adalah tingkat pertumbuhan ritel tertinggi yang pernah dialami oleh Indonesia sejak 2001 lalu (www. radarpena.com).

Terdapat tiga ritel yang ada di Indonesia, ketiga ritel itu adalah Alfamart, Indomaret, dan Seven Eleven (Bachdar, 2015). Dari ketiga ritel tersebut, persaingan yang paling ketat adalah persaingan antara Alfamart dan Indomaret. Kedua ritel tersebut berencana akan terus memperluas ekspansi gerai mereka. Di tahun 2015, Indomaret berencana mencapai pertumbuhan gerai sebesar $20 \%-25 \%$ dari total
10.816 gerai yang sudah mereka miliki. Selain itu, Indomaret juga berencana memfokuskan pertumbuhan tersebut di pulau Jawa. Di lain sisi, Alfamart juga terus berupaya untuk bersaing dengan pesaing utamanya tersebut. Alfamart selama tahun 2015 berencana membuka 1200 gerai baru, dan 50\% gerai tersebut mereka fokuskan di luar pulau Jawa (Bachdar, 2015). Untuk meningkatkan daya saing tersebut, dibutuhkan strategi pemasaran untuk meningkatkan penjualan dan menarik konsumen sebanyak mungkin. Strategi yang populer digunakan dalam rencana pemasaran untuk mengatasi persaingan pasar adalah komunikasi pemasaran terpadu atau Integrated Marketing Communication (IMC) (Suwantara dan Taechamaneesatit, 2012). Terdapat alasan yang melatarbelakangi mengapa perusahaan menggunakan komunikasi pemasaran terpadu, yaitu munculnya pemahaman mengenai pentingnya upaya untuk memadukan berbagai fungsi komunikasi yang tersedia, daripada membiarkan berbagai fungsi komunikasi itu bekerja sendiri-sendiri. Dengan mengoordinasikan segala upaya komunikasi pemasaran yang dilakukan masing-masing bagian, maka perusahaan dapat menghindari terjadinya duplikasi pekerjaan (Morissan, 2010). Komunikasi pemasaran yang 
diintegrasikan ini terdiri dari iklan, promosi penjualan, penjualan personal, hubungan masyarakat, pemasaran langsung, dan interaktif marketing (Kotler \& Keller, 2009). Kemudian untuk pemasaran di sektor jasa terdapat elemen tambahan yaitu corporate design. Konsep komunikasi pemasaran terpadu yang berkembang di tahun 1980an ini didefinisikan oleh Shimp (2010) sebagai sebuah proses komunikasi yang terdiri dari perencanaan, penciptaan, pengintegrasian dan penerapan berbagai bentuk komunikasi pemasaran. Berdasarkan konsep Komunikasi Pemasaran Terpadu, perusahaan akan memadukan dan mengkoordinasikan semua bauran pemasaran untuk menyampaikan pesan yang jelas, konsisten, dan juga memiliki pengaruh yang kuat. Hal ini didukung oleh penjelasan Kotler and Keller (2014) bahwa kegiatan komunikasi pemasaran perlu diintegrasikan untuk menghantarkan pesan yang konsisten dan mencapai positioning yang strategis.

Selama ini Alfamart sudah menerapkan dimensi-dimensi Komunikasi Pemasaran Terpadu terhadap produk-produk mereka. Sebagai contoh seperti melakukan pemasangan iklan di website, pemberian bantuan pembangunan sekolah, product bundling, pemasaran melalui media sosial, dll.Komunikasi pemasaran terpadu ini akan membentuk identitas merek dan citra yang kuat, dimana hal ini akan lebih mendukung pesan yang ingin disampaikan perusahaan melalui merek tertentu. Merek menjadi hal yang penting di dalam persaingan bisnis. Ketika merek sudah tidak asing lagi di pikiran konsumen, maka konsumen tidak akan lama berpikir untuk memutuskan pembelian ulang. Oleh karena itu, sebuah merek harus memiliki kualitas yang baik dan keunikan tersendiri supaya merek tersebut mendapatkan persepsi baik bagi konsumen.

Penelitian terdahulu yang dilakukan oleh Fathoni (2013) menyatakan bahwa variabel dalam komunikasi pemasaran terpadu, yang terdiri dari Iklan, Promosi Penjualan, Penjualan Personal, Hubungan Masyarakat, Pemasaran Langsung, Pemasaran Interaktif dan Corporate design berpengaruh terhadap ekuitas merek Hotel Pelangi di Malang.
Penelitian serupa juga pernah dilakukan oleh Kartikasari (2014), hasilnya variabel promosi penjualan, penjualan personal, dan hubungan masyarakat secara bersamasama berpengaruh terhadap ekuitas merek hotel di Semarang. Selain itu, Danibrata (2011) dalam penelitiannya menyatakan bahwa variabel iklan, promosi penjualan, hubungan masyarakat, dan Corporate design berpengaruh signifikan terhadap ekuitas merek Bank Pemerintah di Jakarta. Prayitno (2010) juga menyimpulkan bahwa iklan, promosi penjualan, hubungan masyarakat, dan pemasaran interaktif berpengaruh signifikan terhadap ekuitas merek Bank BUMN di Jakarta, Medan dan Surabaya.

Penelitian terdahulu melakukan penelitian dengan mengambil obyek di sektor jasa, seperti Fathoni (2013) dan Kartikasari (2014) meneliti tentang hotel, sedangkan Danibrata (2011) dan Prayitno (2010) meneliti tentang bank. Kemudian untuk penelitian ini, peneliti ingin melakukan replikasi dari penelitian yang dilakukan oleh Fathoni (2013) dengan mengganti obyek penelitian menjadi ekuitas merek Alfamart. Hal ini dikarenakan di dalam penelitian Fathoni memiliki variabel komunikasi pemasaran terpadu yang lengkap, dan juga masih minimnya penelitian yang membahas tentang komunikasi pemasaran terpadu terhadap ekuitas merek dalam bisnis ritel.

Daripenjabaran diatas, masalah penelitian yang dirumuskan adalah pengaruh komunikasi pemasaran terpadu terhadap ekuitas merek Alfamart.Berdasarkan latar belakang yang ada, persoalan penelitiannya adalah apakah dimensi dari komunikasi pemasaran terpadu yang terdiri dari iklan, promosi penjualan, penjualan personal, hubungan masyarakat, pemasaran langsung, pemasaran interaktif, dan Corporate design berpengaruh terhadap ekuitas merekAlfamart? Oleh karena itu, tujuan dari penelitian ini adalah untuk menjelaskan dimensi dari komunikasi pemasaran terpadu yang terdiri dari iklan, promosi penjualan, penjualan personal, hubungan masyarakat, pemasaran langsung, pemasaran interaktif, dan Corporate design yang berpengaruh terhadap ekuitas merek Alfamart. 


\section{TINJAUAN LITERATUR}

Komunikasi Pemasaran Terpadu/Integrated Marketing Communication (IMC)

Komunikasi Pemasaran Terpadu mengintegrasikan dan mengkoordinasikan berbagai saluran komunikasi perusahaan untuk menghantarkan pesan yang jelas, konsisten, dan menarik tentang organisasi dan produknya (Kotler \& Amstrong, 2008). Belch dan Belch (2009) menjelaskan bahwa pengertian komunikasi pemasaran terpadu merupakan sebuah konsep perencanaan komunikasi pemasaran yang menyadari nilai tambah dari suatu rencana komprehensif yang mengevaluasi peran strategis dari berbagai disiplin komunikasi. Contoh dari hal ini adalah komunikasi umum, tanggapan langsung, promosi penjualan dan hubungan masyarakat serta menggabungkan berbagai hal ini untuk memberikan kejelasan, konsistensi, dan pengaruh komunikasi yang maksimum melalui integrasi menyeluruh dari pesan-pesan yang berlainan. Komunikasi Pemasaran Terpadu juga merupakan sebuah konsep pemasaran yang menerapkan 6 (enam) strategi pemasaran secara bersama, yaitu Iklan (Advertising), Promosi Penjualan (Sales Promotion), Penjualan Personal (Personal Selling), Hubungan Masyarakat (Public Relations), Pemasaran Langsung (Direct marketing), dan Pemasaran Interaktif (Interactive Marketing). Untuk pemasaran di sektor jasa terdapat elemen tambahan yaitu corporate design.

\section{Iklan (Advertising)}

Advertising adalah bentuk pembayaran dari komunikasi nonpersonal tentang sebuah organisasi, produk, pelayanan atau ide melalui sponsor yang teridentifikasi (Belch \& Belch, 2009). Secara umum iklan membantu menjelaskan akan suatu produk, sedangkan bagi perusahaan itu sendiri iklan merupakan suatu alat pemasar yang sangat penting bagi perusahaan. Kotler dan Keller (2014) menyatakan bahwa iklanadalah segala bentuk presentasi non-pribadi dan promosi gagasan, barang, atau jasa oleh sponsor tertentu yang harus dibayar. Banyak perusahaan melakukan advertising untuk membuat customer dari unaware menjadi aware akan suatu produk yang diluncurkan oleh perusahaan tersebut.
Iklan dapat berupa iklan tayangan (tv), iklan di media cetak atau ulasan di media cetak seperti surat kabar dan majalah, kemasan, radio, brosur, poster dan selebaran, stiker, papan iklan, dan internet. Iklan ini bertujuan untuk lebih mengenalkan suatu produk atau merek kepada masyarakat. Seseorang cenderung membeli sebuah barang ketika merek tersebut tidak asing lagi bagi masyarakat. Penelitian yang dilakukan oleh Danibrata (2011) menunjukkan adanya pengaruh iklan terhadap ekuitas merek Bank Pemerintah di Jakarta. Berdasarkan penjabaran diatas, diajukan hipotesa pertama sebagai berikut:

Hipotesa 1: Iklan berpengaruh terhadap ekuitas merek Alfamart

\section{Promosi Penjualan (Sales Promotion)}

Morissan (2010) menjelaskan bahwa promosi penjualan dapat dibedakan menjadi dua bagian, yaitu promosi penjualan yang berorientasi kepada konsumen (consumeroriented sales promotion) dan promosi penjualan yang berorientasi pada perdagangan (trade-oriented sales promotion). Pada dasarnya sales promotion dibuat untuk lebih mempercepat respons dari konsumen dengan pemberian nilai tambah kepada suatu barang. Konsep sales promotion seperti ini digunakan untuk memotivasi konsumen agar melakukan pembelian produk yang dipicu dengan adanya penawaran produk selama jangka waktu terbatas. Hal ini didukung dengan pendapat Peter dan Donelly (2011) bahwa sales promotion merupakan sebuah kegiatan atau materi yang menawarkan pelanggan, tenaga penjualan, dan reseller sebuah bujukan langsung untuk membeli produk.

Berbagai perusahaan mencoba melakukan beberapa macam promosi dengan maksud untuk lebih menarik konsumen untuk datang berbelanja. Promosi penjualan adalah berbagai insentif jangka pendek untuk mendorong percobaan atau pembelian produk atau jasa. Promosi penjualan dapat berupa sampel, kupon, premi (hadiah) berupa bonus atau potongan harga, penurunan harga, bazaar dan pameran dagang dan pameran demonstrasi (Kotler \& Keller, 2009). Dengan adanya promosi, konsumen akan lebih tertarik 
untuk memutuskan membeli suatu barang dan juga akan mengingat merek yang memberikan promosi tersebut. Penelitian yang dilakukan oleh Kartikasari (2014) menunjukkan adanya pengaruh promosi penjualan terhadap ekuitas merek Hotel di Semarang. Berdasarkan penjabaran di atas, diajukan hipotesa kedua sebagai berikut:

Hipotesa 2: Promosi Penjualan berpengaruh terhadap ekuitas merek Alfamart

\section{Penjualan Personal (Personal Selling) \\ Personal selling adalah suatu bentuk} komunikasi langsung antara seorang penjual dengan calon pembelinya (Morissan, 2010). Personal seling merupakan komunikasi personal yang dilakukan oleh perusahaan dengan tujuan untuk membuat penjualan dan membangun hubungan dengan konsumen (Kotler \& Keller, 2014). Personal selling sendiri merupakan bagian dari direct marketing, hanya saja dalam personal selling, perusahaan dijembatani oleh seorang sales person yang berinteraksi secara tatap muka dengan customer.

Penjualan personal dilakukan oleh perusahaan supaya ada interaksi dua arah yang terjadi antarakonsumen dan perusahaan. Dalam hal ini, penjualan personal bisa dilakukan melalui wiraniaga yang memberikan tawaran secara langsung kepada konsumen. Tidak hanya tawaran, tetapi sikap ramah wiraniaga juga akan membuat konsumen merasa lebih terlayani, sehingga hal ini akan melekat di benak konsumen. Penelitian yang dilakukan oleh Fathoni (2013) menunjukkan adanya pengaruh penjualan personal terhadap ekuitas merek Hotel Pelangi Malang. Berdasarkan penjabaran di atas, diajukan hipotesa ketiga sebagai berikut:

Hipotesa 3: Penjualan Personal berpengaruh terhadap ekuitas merek Alfamart.

\section{Hubungan Masyarakat Relations)}

Public relation adalah fungsi manajemen yang membangun dan mempertahankan hubungan yang baik dan bermanfaat antara organisasi dengan publik yang memengaruhi kesuksesan atau kegagalan organisasi tersebut (Cutlip, Allen \& Glenn, 2006).
Ketika suatu organisasi merencanakan dan mendistribusikan informasi secara sistematis dalam upaya untuk mengontrol dan mengelola citra serta publisitas yang diterimanya, maka perusahaan itu sedang menjalankan tugas hubungan masyarakat (Belch \& Belch, 2009). Hubungan masyarakat dilakukan oleh perusahaan sebagai bentuk kepedulian perusahaan akan lingkungan sekitar. Hubungan masyarakat bisa diwujudkan melalui beragam program yang dirancang untuk mempromosikan atau melindungi citra perusahaan atau produk individunya. Hubungan masyarakat dan publisitas dapat berupa pidato, seminar, laporan tahunan, donasi amal, publikasi, hubungan komunitas, lobi, dan kegiatan layanan masyarakat (Kotler \& Keller, 2009). Dengan berjalannya hubungan masyarakat yang baik akan berdampak pada kelangsungan perusahaan ke depannya. Penelitian terdahulu yang dilakukan oleh Prayitno (2010) menunjukkan adanya pengaruh hubungan masyarakat terhadap penciptaan ekuitas merek. Berdasarkan penjabaran di atas, diajukan hipotesa keempat sebagai berikut:

Hipotesa 4: Hubungan Masyarakat berpengaruh terhadap Ekuitas Merek Alfamart

\section{Pemasaran Langsung (Direct marketing)}

Direct marketing merupakan salah satu fungsi IMC yang terdiri dari frontend dan back end operations.Front-end ini mencakup sebuah penawaran yang diberikan kepada konsumen, misalnya saja dengan menawarkan harga khusus dan juga pemberian garansi. Di bagian front-end juga menawarkan the database, yaitu mendapatkan dan menggunakan data konsumen untuk penawaran yang selanjutnya, dan juga the response, yaitu memberikan respon terhadap konsumen melalui layanan customer service bebas pulsa. Kemudian back end merupakan usaha untuk memenuhi ekspektasi konsumen dengan membuat produk atau informasi yang sesuai seperti yang ada di benak konsumen.

Morrisan (2010) menjelaskan pemasaran langsung atau direct marketing adalah upaya perusahaan atau organisasi untuk berkomunikasi secara langsung dengan calon pelanggan sasaran dengan maksud untuk 
menimbulkan tanggapan dan/atau transaksi penjualan. Dengan kata lain, pemasaran langsung disini tidak hanya mengirim surat (direct mail) dan mengirim katalog perusahaan (mail-order catalogs), tetapi juga mencakup pengelolaan database (database management) dan juga penjualan langsung (direct selling). Direct marketing ini merupakan sistem pemasaran yang menggunakan saluran langsung untuk mencapai konsumen dan menyerahkan barang dan jasa kepada konsumen tanpa melalui perantara pemasaran (Suyanto, 2007).

Pemasaran langsung dilakukan oleh perusahaan dengan harapan bisa langsung mendapatkan feedback dari konsumen. Pemasaran langsung yang saat ini kerap digunakan adalah pemasaran dengan menggunakan penggunaan surat, telepon atau telemarketing, faksimile, katalog, e-mail dan telepon untuk berkomunikasi secara langsung dengan meminta respons atau dialog dari pelanggan dan prospek tertentu (Kotler \& Keller, 2009). Dalam bisnis ritel, yang kerap dilakukan adalah dengan menggunakan katalog. Katalog ini akan membantu memberi informasi kepada konsumen akan programprogram yang sedang berjalan, ketika wiraniaga belum mampu menyampaikannya dengan maksimal. Berdasarkan penjabaran di atas, diajukan hipotesa kelima sebagai berikut:

Hipotesa 5: Pemasaran langsung berpengaruh terhadap ekuitas merek Alfamart

\section{Pemasaran Interaktif}

Pemasaran Interaktif adalah aktivitas online dan program yang didesain untuk meningkatkan kesadaran konsumen, memperbaiki citra, dan membuat penjualan akan suatu barang dan jasa (Kotler \& Keller, 2009). Sedangkan menurut Reedy et al. (2000), pemasaran interaktif adalah keseluruhan aktivitas dengan menggunakan media online yang bertujuan memfasilitasi proses produksi barang dan jasa dari produsen dalam rangka memenuhi kebutuhan dan keinginan konsumen.

Pemasaran interaktif merupakan salah satu cara yang dilakukan oleh perusahaan untuk menjangkau konsumen secara lebih luas. Hampir semua perusahaan memiliki website yang berisi segala hal mengenai perusahaan mereka. Dengan cara seperti ini, konsumen akan lebih leluasa untuk mencari informasi akan suatu merek. Karena di era digital seperti sekarang ini, masyarakat bisa dengan mudah terkoneksi dengan internet dan mencari informasi apapun yang mereka inginkan. Penelitian yang dilakukan Prayitno (2010) menunjukkan adanya pengaruh pemasaran interaktif terhadap penciptaan ekuitas merek. Berdasarkan penjabaran di atas, diajukan hipotesa kelima sebagai berikut:

Hipotesa 6: Pemasaran Interaktif berpengaruh terhadap ekuitas merek Alfamart

\section{Corporate Design}

Corporate design atau rancangan korporat adalah kunci dalam menjamin konsistensi gaya dan pesan yang disampaikan melalui saluran bauran komunikasi perusahaan (Lovelock et al, 2010). Corporate design menggambarkan outlet jasa, baik pesan yang direncanakan maupun tidak direncanakan akan menjangkau pelanggan melalui media lingkungan penghantaran jasa. Outlet jasa yang di dalamnya terdapat diantaranya spanduk, poster, papan nama, brosur, layar video, dan audio. Komponen corporate design lainnya adalah termasuk tenaga penjual (wiraniaga) yang dapat melayani pelanggan melalui tatap muka langsung, melalui telepon atau email. Corporate design penting bagi perusahaan yang bergerak dalam pasar kompetitif guna menonjolkan identitas perusahaan supaya dapat dikenali dengan mudah dimanapun.

Kondisi ruangan yang baik akan membuat konsumen merasa nyaman berada di dalamnya. Tidak hanya kondisi ruangan, tetapi juga orang yang bertugas melayani yang berada di dalam ruangan tersebut juga berpengaruh kepada kenyamanan konsumen. Dalam hal ini adalah wiraniaga. Ketika wiraniaga mampu memberikan pelayanan yang baik, hal ini akan melekat di benak konsumen, sehingga di lain waktu konsumen akan mengingat apa yang dialami oleh mereka. Corporate design atau rancangan korporat adalah kunci dalam menjamin konsistensi gaya dan pesan yang disampaikan melalui saluran bauran komunikasi perusahaan (Lovelock et al, 2010). Penelitian yang dilakukan oleh Danibrata (2011) menunjukkan adanya pengaruh Corporate design terhadap ekuitas merek 
Bank Pemerintah di Jakarta. Berdasarkan penjabaran diatas, diajukan hipotesa ketujuh sebagai berikut:

Hipotesa 7: Corporate Design berpengaruh terhadap ekuitas merek Alfamart

\section{Ekuitas Merek}

Ekuitas merek merupakan efek diferensial dimana nama dari sebuah merek berada dalam pikiran konsumen akan sebuah produk dan pemasaran tertentu (Kotler \& Keller, 2014). Merek memungkinkan bagi perusahaan untuk berkompetisi dalam pasar produk dan jasa serta menunjukkan proposisi nilai dari strategi bisnis. Dengan kata lain, sangat penting untuk mengembangkan, menyaring, dan mendongkrak aset merek.

\section{Model Penelitian}

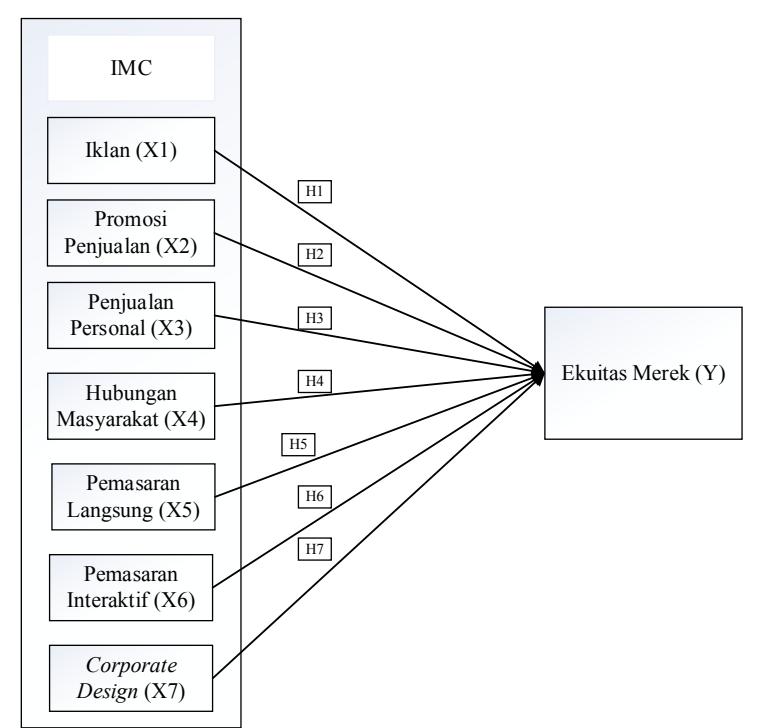

Gambar 1. Model Penelitian

Sumber : Fathoni (2013)

METODE PENELITIAN

Jenis penelitian dalam penelitian ini adalah penelitian kuantitatif. Populasi dalam penelitian ini adalah konsumen Alfamart Salatiga. Teknik pengumpulan sampel dalam penelitian ini adalah purposive sampling, dengan kriteria responden yang sudah pernah berbelanja di Alfamart Salatiga. Sebagai sampel dari penelitian ini adalah 150 orang responden konsumen Alfamart Salatiga. Teknik analisis yang digunakan adalah regresi linier berganda.

\section{HASIL DAN PEMBAHASAN}

\section{Karakteristik Responden}

Padabagianiniakandiuraikankarakteristik responden yang sudah diklasifikasikan oleh peneliti menjadi beberapa bagian, seperti Usia, Jenis Kelamin, Pekerjaan, Penghasilan yang diterima responden setiap bulan, Frekuensi responden berkunjung ke Alfamart setiap Minggu, dan alasan responden berbelanja di Alfamart.

Karakteristik responden dalam penelitian ini akan dijelaskan pada tabel 1. Berdasarkan data di bawah, responden yang berusia 1618 tahun berjumlah paling banyak dengan prosentase 48\%, kemudian responden berusia 19-21 tahun sebesar 31,3\%, sehingga responden berusia 16-21 tahun memiliki jumlah sebesar $70 \%$. Hal ini dikarenakan ketika peneliti membagikan kuesioner, responden pada interval inilah yang lebih sering dijumpai oleh peneliti. Berdasarkan jenis kelamin, lebih didominasi oleh responden yang berjenis kelamin perempuan, yaitu sebesar 54,7\%. Kemudian dari kategori pekerjaan, mayoritas responden berstatus sebagai mahasiswa, yaitu sebesar $77,3 \%$. Hal ini dikarenakan peneliti juga masih berstatus mahasiswa sehingga peneliti lebih memiliki banyak relasi dengan mahasiswa dibanding dengan kategori pekerjaan yang lainnya. 
Tabel 1. Karakteristik Responden

\begin{tabular}{|c|c|c|c|c|}
\hline No & Kategori & Sub Kategori & Frekuensi & Prosentase \\
\hline \multirow{4}{*}{1} & \multirow{4}{*}{ Usia } & 16-18 tahun & 72 & $48,00 \%$ \\
\hline & & 19-21 tahun & 47 & $31,30 \%$ \\
\hline & & 22-24 tahun & 12 & $8,00 \%$ \\
\hline & & 25-27 tahun & 19 & $12,70 \%$ \\
\hline \multirow{3}{*}{2} & \multirow{3}{*}{$\begin{array}{l}\text { Jenis } \\
\text { Kelamin }\end{array}$} & Laki-laki & 68 & $45,30 \%$ \\
\hline & & Perempuan & 82 & $54,70 \%$ \\
\hline & & Pelajar & 6 & $4,00 \%$ \\
\hline \multirow[t]{2}{*}{3} & Pekerjaan & Mahasiswa & 116 & $77,30 \%$ \\
\hline & & Pegawai Swasta & 28 & $18,70 \%$ \\
\hline \multirow[t]{4}{*}{4} & $\begin{array}{l}\text { Penghasilan } \\
\text { Per Bulan }\end{array}$ & $<\operatorname{Rp} 1.000 .000,00$ & 64 & $42,70 \%$ \\
\hline & & Rp 1.000.000,00 - Rp 2.000.000,00 & 58 & $38,70 \%$ \\
\hline & & Rp 2.000.000,00 - Rp 3.000.000,00 & 14 & $9,30 \%$ \\
\hline & & $>\operatorname{Rp} 3.000 .000,00$ & 14 & $9,30 \%$ \\
\hline \multirow[t]{4}{*}{5} & $\begin{array}{l}\text { Frekuensi } \\
\text { Belanja Per } \\
\text { Minggu }\end{array}$ & 1 kali & 25 & $16,70 \%$ \\
\hline & & 2 kali & 33 & $22,00 \%$ \\
\hline & & 3 kali & 67 & $44,70 \%$ \\
\hline & & 4 kali & 25 & $16,70 \%$ \\
\hline \multirow[t]{4}{*}{6} & Alasan & Harga Lebih Murah & 22 & $14,70 \%$ \\
\hline & & Nama Sudah Terkenal & 37 & $24,70 \%$ \\
\hline & & Gerai Mudah Dijangkau & 63 & $42,00 \%$ \\
\hline & & Fasilitas Memadai & 28 & $18,70 \%$ \\
\hline
\end{tabular}

Sumber : data primer yang diolah (2016)

Penghasilan per bulan yang paling banyak yaitu di kategori $<\mathrm{Rp}$ 1.000.000,00 sebesar $42,7 \%$, dikarenakan mayoritas responden adalah mahasiswa. Kemudian frekuensi berbelanja di gerai Alfamart per Minggu paling besar dilakukan oleh responden yang berbelanja sebanyak 3 kali per Minggu, yaitu sebesar 44,7\%. Dari kategori alasan berbelanja, mayoritas responden memilih berbelanja di Alfamart karena lokasi gerai yang mudah dijangkau, yaitu sebesar $42 \%$ responden memilih berbelanja di Alfamart dengan alasan ini.

\section{Uji Asumsi Klasik}

Dari hasil pengujian normalitas dengan Kolmogorov Smirnov, didapatkan hasil Asymp. Sig. (2-tailed) sebesar 0.380. Nilai ini lebih besar dari signifikansi yang digunakan dalam penelitian ini yaitu sebesar
$5 \%$ atau 0.05 , sehingga dapat disimpulkan data berdistribusi normal. Kemudian peneliti melakukan uji multikolinearitas, dimana uji ini digunakan untuk mengetahui ada tidaknya korelasi antar variabel bebas. Dari hasil uji multikolinearitas didapatkan hasil Tolerance $>0.10$ dan VIF $<10.00$, sehingga dapat disimpulkan bahwa data tidak terjadi multikolinearitas. Selanjutnya dilakukan uji heterokedastisitas untuk melihat terjadinya ketidaksamaan varian dari residual pada model regresi. Uji heterokedastisitas ini dilakukan dengan melihat grafik scatterplot. Hasil dari grafik tersebut terlihat bahwa titik-titik tidak membentuk pola tertentu dan menyebar secara tidak beraturan, sehingga bisa disimpulkan bahwa tidak terjadi heterokedastisitas. Hasil dari ketiga uji diatas membuktikan bahwa data penelitian ini sudah lolos uji asumsi klasik. Berikut adalah scatterplotnya. 


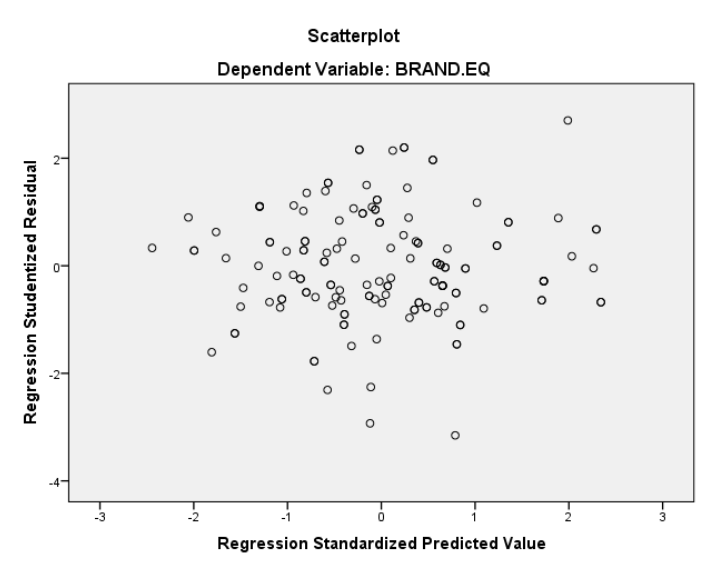

Gambar 1. Scatterplot Uji Hetereskedastisitas Sumber: Data Primer Yang Diolah (2016)

\section{Analisis Regresi Linier Berganda}

Setelah data terbukti lolos uji asumsi klasik, peneliti akan melanjutkan dengan uji regresi linier berganda. Model analisis ini digunakan untuk mengetahui besarnya pengaruh dimensi Komunikasi Pemasaran Terpadu (X) yang terdiri dari Iklan (X1), Promosi Penjualan (X2), Penjualan Personal (X3), Hubungan Masyarakat (X4), Pemasaran Langsung (X5), Pemasaran Interaktif (X6), dan Corporate design (X7) dengan Ekuitas Merek Alfamart (Y).

\section{Uji t}

Untuk mengetahui pengaruh variabel bebas terhadap variabel terikat secara parsial dan untuk mengetahui variabel manakah yang memiliki pengaruh dominan, maka digunakan uji t. Apabila signifikansinya lebih kecil dari $0,05(p<0,05)$, maka variabel tersebut memiliki pengaruh signifikan secara parsial. Secara parsial penjelasannya dapat dijelaskan sebagai berikut:

Tabel 2. Hasil Uji t

Coefficients $^{\mathrm{a}}$

\begin{tabular}{|c|c|c|c|c|c|c|}
\hline & \multirow[t]{2}{*}{ Model B } & \multicolumn{2}{|c|}{ Unstandardized Coefficients } & \multirow[t]{2}{*}{$\begin{array}{c}\text { Standardized } \\
\text { Coefficients }\end{array}$} & \multirow[t]{2}{*}{$\mathrm{t}$} & \multirow[t]{2}{*}{ Sig. } \\
\hline & & Std. Error & Beta & & & \\
\hline \multirow{8}{*}{1} & (Constant) & 1.590 & 1.068 & & 1.489 & .139 \\
\hline & $\mathrm{x} 1$ & .095 & .060 & .123 & 1.579 & .117 \\
\hline & $\mathrm{x} 2$ & .235 & .075 & .232 & 3.132 & .002 \\
\hline & $\mathrm{x} 3$ & .125 & .058 & .147 & 2.172 & .032 \\
\hline & $\mathrm{x} 4$ & .066 & .075 & .063 & .880 & .380 \\
\hline & $x 5$ & -.051 & .063 & -.057 & -.804 & .423 \\
\hline & $x 6$ & .065 & .046 & .109 & 1.393 & .166 \\
\hline & $\mathrm{x} 7$ & .297 & .056 & .361 & 5.293 & .000 \\
\hline Depe & dent Variable: y & & & & & \\
\hline
\end{tabular}

Sumber : Data primer diolah (2016)

Dari hasil analisis regresi dapat diketahui persamaan regresi berganda sebagai berikut:

$$
\begin{aligned}
\mathrm{Y}= & 1,590+0,095 \mathrm{X} 1+0,235 \mathrm{X} 2+0,125 \mathrm{X} 3+ \\
& 0,066 \mathrm{X} 4-0,051 \mathrm{X} 5+0,065 \mathrm{X} 6+0,297 \mathrm{X} 7
\end{aligned}
$$

Y : Ekuitas Merek Alfamart

$\mathrm{X} 1$ : Iklan

$\mathrm{X} 2$ : Promosi Penjualan

X3 : Penjualan Personal

X4 : Hubungan Masyarakat

X5 : Pemasaran Langsung

X6 : Pemasaran Interaktif

X7 : Corporate design
Berdasarkan persamaan tersebut, maka dapat dijelaskan sebagai berikut:

1. Nilai konstanta sebesar 1,590. Artinya jika Iklan, Promosi Penjualan, Penjualan Personal, Hubungan Masyarakat, Pemasaran Langsung, Pemasaran Interaktif, Corporate design tetap atau tidak mengalami penambahan atau pengurangan, maka nilai Ekuitas Merek Alfamart akan sebesar nilai konstanta, yaitu 1.590 .

2. Nilai Koefisien Iklan untuk dimensi X1 sebesar 0,095. Koefisien bernilai positif, artinya terjadi hubungan positif antara Iklan dan Ekuitas Merek Alfamart (Y). 
Jika Iklan mengalami kenaikan, maka variabel Ekuitas Merek Alfamart (Y) akan ikut naik.

3. Nilai Koefisien Promosi Penjualan untuk dimensi X2 sebesar 0,235. Koefisien bernilai positif, artinya terjadi hubungan positif antara Promosi Penjualan dan Ekuitas Merek Alfamart (Y). Jika Promosi Penjualan mengalami kenaikan, maka variabel Ekuitas Merek Alfamart (Y) akan ikut naik.

4. Nilai Koefisien Penjualan Personal untuk dimensi X3 sebesar 0,125. Koefisien bernilai positif, artinya terjadi hubungan positif antara Penjualan Personal dan Ekuitas Merek Alfamart (Y). Jika Penjualan Personal mengalami kenaikan, maka variabel Ekuitas Merek Alfamart (Y) akan ikut naik.

5. Nilai Koefisien Hubungan Masyarakat untuk dimensi X4 sebesar 0,066. Koefisien bernilai positif, artinya terjadi hubungan positif antara Hubungan Masyarakat dan Ekuitas Merek Alfamart (Y). Jika Hubungan Masyarakat mengalami kenaikan, maka variabel Ekuitas Merek Alfamart (Y) akan ikut naik.

6. Nilai Koefisien Pemasaran Langsung untuk dimensi X5 sebesar -0,051. Koefisien bernilai negatif, artinya terjadi hubungan negatif antara Pemasaran
Langsung dan Ekuitas Merek Alfamart (Y). Jika Pemasaran Langsung mengalami kenaikan, maka variabel Ekuitas Merek Alfamart (Y) akan turun.

7. Nilai Koefisien Pemasaran Interaktif untuk dimensi X6 sebesar 0,065. Koefisien bernilai positif, artinya terjadi hubungan positif antara Pemasaran Interaktif dan Ekuitas Merek Alfamart (Y). Jika Pemasaran Interaktif mengalami kenaikan, maka variabel Ekuitas Merek Alfamart (Y) akan ikut naik.

8. Nilai Koefisien Corporate design untuk dimensi X7 sebesar 0,297. Koefisien bernilai positif, artinya terjadi hubungan positif antara Corporate design dan Ekuitas Merek Alfamart (Y). Jika Corporate design mengalami kenaikan, maka variabel Ekuitas Merek Alfamart (Y) akan ikut naik.

\section{Uji F}

Analisis regresi berganda dengan menggunakan uji $\mathrm{F}$ bertujuan untuk mengetahui pengaruh variabel bebas terhadap variabel terikat secara bersama-sama. Apabila nilai signifikansi lebih kecil dari 0.05, maka model regresi signifikan. Hasil dan penjelasan uji F dijelaskan sebagai berikut :

Tabel 3. Hasil Uji F

\begin{tabular}{cccccc}
\hline \multicolumn{1}{c}{ Model Summary $^{\mathbf{b}}$} \\
\hline Model & $\mathbf{R}$ & $\begin{array}{c}\text { R } \\
\text { Square }\end{array}$ & $\begin{array}{c}\text { Adjusted R } \\
\text { Square }\end{array}$ & $\begin{array}{c}\text { Std. Error } \\
\text { of the } \\
\text { Estimate }\end{array}$ & $\begin{array}{c}\text { Durbin- } \\
\text { Watson }\end{array}$ \\
\hline 1 & $.687^{\mathrm{a}}$ & .472 & .446 & 1.382 & 2.046
\end{tabular}

a. Predictors: (Constant), x7, x5, x3, x4, x2, x6, x1

b. Dependent Variable: y

\begin{tabular}{ccccccc}
\hline & \multicolumn{9}{c}{ ANOVA $^{\text {a }}$} \\
\hline \multirow{2}{*}{ Model } & $\begin{array}{c}\text { Sum of } \\
\text { Squares }\end{array}$ & df & $\begin{array}{c}\text { Mean } \\
\text { Square }\end{array}$ & F & Sig. \\
& Regression & 242.385 & 7 & 34.626 & 18.120 & $.000^{\mathrm{b}}$ \\
\multirow{3}{*}{1} & Residual & 271.358 & 142 & 1.911 & & \\
& Total & 513.743 & 149 & & &
\end{tabular}

a. Dependent Variable: y

b. Predictors: (Constant), x7, x5, x3, x4, x2, x6, x1

Sumber : Data primer diolah (2016)

Berdasarkan Tabel 3, diketahui nilai 2,075 dengan signifikansi sebesar 0,000. hitung F sebesar 18,120, dan F tabel sebesar Karena F hitung $>$ F tabel dan nilai signifikansi 
lebih kecil dari 0,05, maka dapat disimpulkan bahwa dimensi Komunikasi Pemasaran Terpadu (X) yang terdiri dari Iklan (X1), Promosi Penjualan (X2), Penjualan Personal (X3), Hubungan Masyarakat (X4), Pemasaran Langsung (X5), Pemasaran Interaktif (X6), dan Corporate design (X7) berpengaruh bersama-sama terhadap variabel terikat yaitu Ekuitas Merek Alfamart (Y). Besarnya kontribusi dimensi Komunikasi Pemasaran Terpadu (X) terhadap Ekuitas Merek Alfamart (Y) dapat dilihat dari nilai adjusted $R$ Square sebesar 0.446 atau sebesar $44,6 \%$, sedangkan $53,4 \%$ sisanya dipengaruhi oleh variabel lain yang tidak diteliti dalam penelitian ini.

Kemudian untuk mengetahui apakah hipotesis yang diajukan dalam penelitian ini diterima atau ditolak, maka dilakukan pengujian hipotesis dengan menggunakan uji $t$ dan uji F. Hasil pengujian hipotesis dijelaskan sebagai berikut:

1. Pengaruh Iklan (X1) Terhadap Ekuitas Merek Alfamart (Y)

2. Hasil dari analisis regresi secara parsial yang dilakukan, besarnya pengaruh Iklan (X1) terhadap Ekuitas Merek Alfamart (Y) dapat dilihat dari koefisien regresi $b$ yaitu sebesar 0,095 dengan signifikansi $0,117$ ( $p>0,05)$, menunjukkan bahwa dimensi Iklan (X1) tidak berpengaruh signifikan terhadap Ekuitas Merek Alfamart (Y).

3. Pengaruh Promosi Penjualan (X2) Terhadap Ekuitas Merek Alfamart (Y)

4. Hasil dari analisis regresi secara parsial yang dilakukan, besarnya pengaruh Promosi Penjualan (X2) terhadap Ekuitas Merek Alfamart (Y) dapat dilihat dari koefisien regresi $\mathrm{b}$ yaitu sebesar 0,235 dengan signifikansi $0,002 \quad(p<0,05)$, menunjukkan bahwa dimensiPromosi Penjualan (X2) berpengaruh signifikan terhadap Ekuitas Merek Alfamart (Y).

5. Pengaruh Penjualan Personal (X3) Terhadap Ekuitas Merek Alfamart (Y)

6. Hasil dari analisis regresi secara parsial yang dilakukan, besarnya pengaruh Penjualan Personal (X3) terhadap Ekuitas Merek Alfamart (Y) dapat dilihat dari koefisien regresi b yaitu sebesar 0,125 dengan signifikansi $0,032 \quad(p<0,05)$, menunjukkan bahwa dimensiPenjualan Personal (X3) berpengaruh signifikan terhadap Ekuitas Merek Alfamart (Y).

7. Pengaruh Hubungan Masyarakat (X4) Terhadap Ekuitas Merek Alfamart (Y)

8. Hasil dari analisis regresi secara parsial yang dilakukan, besarnya pengaruh Hubungan Masyarakat (X4) terhadap Ekuitas Merek Alfamart (Y) dapat dilihat dari koefisien regresi $b$ yaitu sebesar 0,066 dengan signifikansi $0,380(p>0,05)$, menunjukkan bahwa dimensiHubungan Masyarakat (X4) tidak berpengaruh signifikan terhadap Ekuitas Merek Alfamart (Y).

9. Pengaruh Pemasaran Langsung (X5) Terhadap Ekuitas Merek Alfamart (Y)

10. Hasil dari analisis regresi secara parsial yang dilakukan, besarnya pengaruh Pemasaran Langsung (X5) terhadap Ekuitas Merek Alfamart (Y) dapat dilihat dari koefisien regresi $b$ yaitu sebesar -0.051 dengan signifikansi $0,423$ ( $\mathrm{p}>0,05)$, menunjukkan bahwa dimensiPemasaran Langsung (X5) tidak berpengaruh signifikan terhadap Ekuitas Merek Alfamart (Y).

11. Pengaruh Pemasaran Interaktif (X6) Terhadap Ekuitas Merek Alfamart (Y)

12. Hasil dari analisis regresi secara parsial yang dilakukan, besarnya pengaruh Pemasaran Interaktif (X6) terhadap Ekuitas Merek Alfamart (Y) dapat dilihat dari koefisien regresi $b$ yaitu sebesar 0.065 dengan signifikansi $0.166(p>0,05)$, menunjukkan bahwa dimensiPemasaran Interaktif (X6) tidak berpengaruh signifikan terhadap Ekuitas Merek Alfamart (Y).

13. Pengaruh Corporate design (X7) Terhadap Ekuitas Merek Alfamart (Y)

14. Hasil dari analisis regresi secara parsial yang dilakukan, besarnya pengaruh Corporate design (X7) terhadap Ekuitas Merek Alfamart (Y) dapat dilihat dari koefisien regresi b yaitu sebesar 0,297 dengan signifikansi $0,000 \quad(p<0,05)$, menunjukkan bahwa dimensi Corporate design (X7) berpengaruh signifikan terhadap Ekuitas Merek Alfamart (Y). 


\section{PEMBAHASAN}

\section{Iklan Tidak Berpengaruh Terhadap Ekuitas Merek Alfamart}

Hal ini bisa disebabkan karena iklan yang dibuat oleh Alfamart di dalam gerai ataupun luar gerai, belum mampu dipahami oleh konsumen, sehingga iklan ini tidak mampu menarik minat untuk berbelanja di Alfamart. Menurut Fill (2009) konsumen memerlukan keterlibatan aktif dengan media iklan yang dilakukan oleh perusahaan. Keterlibatan aktif ini mampu berjalan dengan baik ketika Alfamart juga secara rutin mengeluarkan iklan-iklan mengenai produk yang dijual. Indikator "Alfamart membuat iklan secara rutin" memperoleh scoring rata-rata sebesar 3,10 . Artinya konsumen menilai bahwa Alfamart tidak rutin mengeluarkan iklan, sehingga keterlibatan aktif dengan konsumen tidak berjalan. Scoring rata-rata sebesar 2,78 didapatkan oleh indikator "Iklan Alfamart membuat saya tertarik untuk berbelanja". Hal ini membuktikan bahwa Iklan yang selama ini sudah dibuat oleh Alfamart hanya dipandang biasa saja oleh konsumen, sehingga iklan tersebut belum bisa dikatakan menjadi daya tarik tersendiri bagi konsumen untuk berbelanja di Alfamart.

Menurut hasil wawancara dengan salah satu responden menyatakan

"Kalau aku malah gak tau iklannya Alfamart yang kaya gimana, tapi aku tau kalau Alfamart itu jualan barang yang aku butuhin sehari-hari. Jadi kalau aku belanja ya tinggal belanja aja, gak perlu liat iklannya dulu" (wawancara, 13/02/2016).

Dari hasil wawancara tersebut terlihat bahwa konsumen berbelanja di Alfamart karena barang yang dicari konsumen memang dijual di Alfamart. Sehingga di sini iklan tidak terlalu berpengaruh kepada konsumen tersebut. Hal ini menguatkan teori Habitual Buying yang diungkapkan (Kotler \& Keller, 2009) bahwa konsumen membeli suatu produk berdasarkan kebiasaan, bukan berdasarkan kesetiaan terhadap merek.

Kemudian sebesar 42\% konsumen memilih berbelanja di Alfamart dengan alasan gerai mudah dijangkau. Dari hasil tersebut, bisa dilihat bahwa sebagian besar konsumen memilih berbelanja di Alfamart tidak terpatok pada iklan yang dibuat oleh Alfamart, tetapi karena letak gerai yang memudahkan konsumen, sehingga mereka memutuskan untuk berbelanja di Alfamart. Hasil ini didukung oleh penelitian terdahulu yang dilakukan oleh Fathoni (2013) yang menyebutkan bahwa Iklan tidak berpengaruh signifikan terhadap Ekuitas Merek. Tetapi hasil ini bertolak belakang dengan penelitian terdahulu yang dilakukan oleh Prayitno (2010) dan Danibrata (2011), dimana di dalam penelitian yang mereka lakukan, variabel iklan berpengaruh signifikan terhadap ekuitas merek. Perbedaan ini bisa terjadi dikarenakan obyek penelitian atau iklan yang berbeda.

\section{Promosi Penjualan Berpengaruh Terhadap Ekuitas Merek Alfamart}

Menurut Peter \& Donelly (2011) sales promotion merupakan sebuah kegiatan atau materi yang menawarkan pelanggan, tenaga penjualan, dan reseller sebuah bujukan langsung untuk membeli produk. Salah satu usaha bujukan langsung yang dilakukan Alfamart untuk promosi penjualan adalah dengan menjual beberapa produk menjadi satu paket penjualan, atau biasa disebut dengan product bundling. Hal ini terbukti efektif untuk menarik minat konsumen. Terbukti dengan indikator "Saya tertarik dengan Product Bundling yang diberikan Alfamart" memperoleh rata-rata scoring sebesar 3.16. Tidak hanya dengan Product bundling, Alfamart juga menetapkan diskon pada beberapa produknya. Dan keputusan diskon ini berhasil membuat konsumen tertarik untuk berbelanja di Alfamart daripada di toko/gerai lain. Scoring rata-rata sebesar 3.41 untuk indikator "Diskon Alfamart bisa bersaing dengan toko/gerai lain" membuktikan bahwa konsumen tertarik dengan diskon yang selama ini diberlakukan oleh Alfamart.

Berdasarkan wawancara dengan salah satu responden, menghasilkan pernyataan sebagai berikut

"aku ga begituperhatian sama diskonnya,
cumamenurutkuyagajauh bedaya diskon
Alfamart sama Indomaret. Ya mirip-
miriplah" (wawancara, 13/02/2016)

"akuga begituperhatian sama diskonnya, cumamenurutkuyagajauh bedaya diskon miriplah" (wawancara, 13/02/2016) 
Dari wawancara tersebut bisa disimpulkan bahwa diskon yang ada di Alfamart bisa bersaing dengan pesaingnya. Kemudian Sebesar 42,7\% konsumen Alfamart dalam penelitian ini memiliki penghasilan per bulan di bawah Rp 1.000.000,00. Jadi dengan adanya product bundling dan diskon ini sesuai dengan harapan konsumen dan terbukti mampu membuat konsumen lebih tertarik untuk melakukan pembelian dengan lebih cepat dan memicu terjadinya pembelian ulang.Hasil ini didukung oleh 4 penelitian terdahulu yang dilakukan oleh Prayitno (2010), Danibrata (2011), Fathoni (2013), dan Kartikasari (2014). Keempat penelitian tersebut sama-sama menyatakan bahwa variabel promosi penjualan berpengaruh signifikan terhadap ekuitas merek.

\section{Penjualan Personal Berpengaruh Terhadap Ekuitas Merek Alfamart}

Personal selling adalah suatu bentuk komunikasi langsung antara seorang penjual dengan calon pembelinya (Morissan, 2010). Penjualan Personal Alfamart ini memang sering dilakukan oleh wiraniaga atau tenaga penjual di setiap gerai Alfamart. Tidak jarang para wiraniaga ini memberikan sapaan-sapaan kepada setiap konsumen yang memasuki gerai Alfamart. Indikator "Wiraniaga Alfamart menyapa saya saat masuk dan keluar dari toko/gerai Alfamart" mendapat scoring ratarata sebesar 3,93 dan membuktikan bahwa wiraniaga Alfamart memberikan sapaansapaan kepada setiap konsumen yang masuk ke gerai Alfamart. Kemudian indikator "Wiraniaga Alfamart bersikap ramah kepada saya" memperoleh scoring rata-rata sebesar 3,94. Sapaan-sapaan dan sikap ramah wiraniaga inilah yang membuat konsumen merasa lebih diterima dan dilayani ketika berbelanja di Alfamart.

Hasil ini didukung oleh penelitian yang dilakukan oleh Fathoni (2013), dimana penelitian tersebut menyebutkan bahwa variabel penjualan personal berpengaruh signifikan terhadap ekuitas merek. Tetapi hasil ini bertolak belakang dengan penelitian yang dilakukan oleh Kartikasari (2014) yang menyebutkan bahwa penjualan personal tidak berpengaruh signifikan terhadap ekuitas merek. Perbedaan ini bisa disebabkan karena berbedanya penjualan personal yang dilakukan dalam penelitian ini dengan penelitian sebelumnya.

\section{Hubungan Masyarakat Tidak Berpengaruh Terhadap Ekuitas Merek Alfamart}

Hubungan Masyarakat adalah fungsi manajemen yang membangun dan mempertahankan hubungan yang baik dan bermanfaat antara organisasi dengan publik yang mempengaruhi kesuksesan atau kegagalan organisasi tersebut (Cutlip et al, 2006). Di dalam website resmi Alfamart sudah tercantum program kemasyarakatan yang bernama Alfamart for All, dimana program ini melibatkan masyarakat di sekitar gerai. Program ini mencakup berbagai aktivitas kegiatan sosial dalam kegiatan CSR (Corporate Social Responsibility) terpadu "Alfamart Sahabat Indonesia" dengan 6 jenis kegiatan, yaitu Alfamart Care, Alfamart Smart, Alfamart Vaganza, Alfamart Sport, Alfamart SMEs, Alfamart Clean \& Green. Hanya saja program-program tersebut tidak terlalu digencarkan di Alfamart Kota Salatiga, sehingga konsumen di Salatiga belum begitu mengetahui program Alfamart for All ini. Hal ini dibuktikan dengan indikator "Alfamart sering melaksanakan tanggung jawab sosialnya" hanya memperoleh rata-rata scoring sebesar 3,19.

Hasil wawancara dengan salah satu responden menyatakan sebagai berikut

"Aku malah gak pernah tau dan gak pernah lihat Alfamart ngadain acara sosial, cuma aku tau kalau kembalian dari Alfamart dalam receh sering diminta untuk didonasikan. Tapi aku juga gak tau hasil donasi jadi kegiatan kaya apa" (wawancara, 13/02/2016).

Dari wawancara tersebut bisa disimpulkan bahwa responden tidak begitu mengetahui seperti apa wujud nyata dari hubungan masyarakat yang dilakukan Alfamart, hanya saja responden mengetahui bahwa Alfamart mengadakan hubungan masyarakat melalui donasi.

Kemudian untuk penilaian konsumen pada indikator "Tanggung jawab sosial yang dilakukan Alfamart pada masyarakat sekitar sudah baik" rata-rata scoring yang didapat 
yaitu sebesar 3,31. Artinya konsumen masih berpikir bahwa tanggung jawab sosial yang dilakukan Alfamart belum begitu maksimal. Dari 150 responden, 116 responden merupakan mahasiswa, sehingga mereka tidak begitu memperhatikan apakah tempat mereka berbelanja melakukan program kemasyarakatan dengan efektif atau tidak.

Hasil penelitian ini didukung oleh penelitian yang dilakukan Fathoni (2013) dan Kartikasari (2014) yang menyatakan bahwa variabel hubungan masyarakat tidak berpengaruh signifikan terhadap ekuitas merek. Tetapi hasil ini berbeda dengan penelitian yang dilakukan oleh Prayitno (2010) dan Danibrata (2011) yang menyatakan variabel hubungan masyarakat berpengaruh signifikan terhadap ekuitas merek. Perbedaan ini disebabkan karena antara penelitian yang satu dengan penelitian yang lain berbeda implementasi hubungan masyarakat yang dilakukan.

\section{Pemasaran Langsung Tidak Berpengaruh Terhadap Ekuitas Merek Alfamart}

Menurut Morrisan (2010) pemasaran langsung atau direct marketing adalah upaya perusahaan atau organisasi untuk berkomunikasi secara langsung dengan calon pelanggan sasaran dengan maksud untuk menimbulkan tanggapan dan/atau transaksi penjualan. Tujuannya yaitu untuk menawarkan produk dan untuk membangun hubungan dengan pelanggan. Alfamart melakukan pemasaran langsung melalui sosial media dan juga katalog belanja. Indikator "Alfamart secara rutin mengeluarkan katalog belanja" mendapat scoring rata-rata sebesar 3.39, sedangkan indikator "Alfamart secara rutin membagikan katalog belanja (ke setiap rumah, di toko/gerai Alfamart, dll)" mendapat scoring rata-rata sebesar 2.86. Artinya konsumen menilai Alfamart sudah cukup rutin untuk mengeluarkan katalog belanja, tetapi tidak rutin dalam membagikan katalog belanjanya, sehingga penyaluran informasi mengenai produk dalam katalog belanja masih belum efektif.

Menurut hasil wawancara dengan salah satu responden, menghasilkan pernyataan sebagai berikut

"Aku tau sih Alfamart punya katalog belanja, tapi ya memang jarang dibagiin sama mbaknya (Wiraniaga), palingan ditaruh di deket kasir. Tapi kalau minta ya nanti dikasih. Aku pernah dapet katalog malah dari Indomaret, bukan dari Alfamart" (wawancara, 13/02/2016).

Dari hasil tersebut bisa dikatakan bahwa Alfamart jarang membagikan katalog belanjanya ke luar gerai, tetapi hanya meletakkan katalog belanjanya di sekitar kasir. Baru ketika konsumen meminta, wiraniaga akan memberikan katalog belanja tersebut.

Untuk sosial media, Alfamart memiliki akun Facebook dalam bentuk Page (Alfamart), Twitter(@alfamart\&@sahabatalfamart),dan jugaLine (@alfamart). Responden di dalam penelitian ini didominasi oleh responden dalam rentang umur 16-21 tahun, dimana dalam rentang umur ini, responden sangat fasih dalam menggunakan sosial media. Tetapi hal ini belum cukup mampu memaksimalkan Ekuitas Merek Alfamart.

Menurut hasil wawancara dengan salah satu responden, menghasilkan pernyataan sebagai berikut

"Aku pernah iseng coba-coba follow Line Officialnya Alfamart, awalnya pengen tau promo waktu lebaran dulu, tapi lamakelamaan kok ngerasa keganggu juga sama chat Linenya. Tiap hari pasti ada chat dari Alfamart, apalagi Linenya ga bisa di delete, cuma bisa di blok, tapi kan blok pun masih masuk itu chatnya" (wawancara, 13/02/2016)

Dari wawancara tersebut dapat disimpulkan bahwa pemasaran langsung yang dilakukan Alfamart hanya menarik minat konsumen pada waktu-waktu tertentu(lebaran, akhir tahun, dll), tetapi selama pada hari-hari biasa, tiap chat yang masuk malah dirasa mengganggu bagi konsumen.

Hasil ini didukung oleh penelitian yang dilakukan oleh Fathoni (2013) yang menyatakan variabel pemasaran langsung berpengaruh negatif terhadap ekuitas merek. Pengaruh negatif ini bisa sama-sama terjadi dalam penelitian yang berbeda, karena efek pemasaran langsung ini sama-sama membuat konsumen merasa tidak nyaman.

\section{Pemasaran Interaktif Tidak Berpengaruh Terhadap Ekuitas Merek Alfamart}

Pemasaran interaktif yang dilakukan Alfamart yaitu melalui website resmi mereka 
di www.alfamartku.com. Adanya website tersebut bertujuan untuk membantu konsumen yang ingin mengetahui lebih lanjut tentang produk dan promosi apa saja yang ada di gerai Alfamart, karena konsumen sekarang memerlukan keterlibatan aktif dengan media yang berisikan informasi produk dari perusahaan (Fill, 2009). Tetapi dalam penelitian ini, dimensi pemasaran interaktif tidak berpengaruh terhadap ekuitas merek Alfamart. Hal ini terlihat dari indikator "Saya sering mencari informasi mengenai promosi di websitewww.alfamartku.com" yang hanya mendapatkan rata-rata scoring 1.97.

Menurut wawancara dengan salah satu responden menghasilkan pernyataan sebagai berikut

"Selama ini kalau aku belanja di Alfamart ya tinggal belanja aja, ga perlu liat websitenya dulu. Kelamaan juga sih ya kalau harus liat websitenya dulu. Nama websitenya apa aja aku gak tau" (wawancara, 13/02/2016).

Dari hasil wawancara tersebut, terlihat bahwa konsumen tidak memperhatikan website Alfamart saat hendak berbelanja. Konsumen berpikir bahwa barang-barang yang dijual di Alfamart adalah barang-barang kebutuhan umum, sehingga ketika ingin berbelanja, konsumen tidak perlu memastikan ke websitenya dahulu apakah barang yang dicari ada di Alfamart.

Kemudian indikator "Informasi produk Alfamart melalui website sudah jelas" memperoleh rata-rata scoring sebesar 2,93 dan indikator "Informasi promosi Alfamart melalui website sudah jelas" memperoleh rata-rata scoring sebesar 3,03. Jadi dapat disimpulkan bahwa konsumen tidak terlalu memperhatikan dan belum cukup terbantu dengan adanya website Alfamart ini. 77,3\% responden dalam penelitian ini adalah mahasiswa, dimana mereka lebih tertarik untuk berbelanja dan langsung merasakan manfaatnya saja, daripada mengeluarkan waktu lebih banyak untuk mengakses website resminya terlebih dahulu hanya untuk melihat harga dan detail produk yang ada.

Hasil penelitian ini berbeda dengan penelitian yang dilakukan oleh Prayitno (2010) dan Fathoni (2013) yang menyebutkan bahwa pemasaran interaktif berpengaruh signifikan terhadap ekuitas merek. Hal ini bisa disebabkan karena perbedaan obyek penelitian dan konten dalam pemasaran interaktif tersebut.

\section{Corporate Design Berpengaruh Terhadap Ekuitas Merek Alfamart}

Corporate design atau rancangan korporat adalah kunci dalam menjamin konsistensi gaya dan pesan yang disampaikan melalui saluran bauran komunikasi perusahaan (Lovelock, 2010). Komponen corporate design termasuk tenaga penjual (wiraniaga) yang dapat melayani pelanggan melalui tatap muka langsung, melalui telepon atau email. Terdapat 2 indikator yang terlihat menonjol dalam dimensi Corporate design ini, yaitu indikator "Karyawan Alfamart memberikan pelayanan dengan baik" yang mendapatkan scoring rata-rata sebesar 3.67 dan indikator "Karyawan Alfamart mampu berkomunikasi dengan baik" mendapatkan scoring ratarata 3.73. Dari hasil 2 indikator tersebut bisa terlihat bahwa karyawan Alfamart bisa memberikan pelayanan yang maksimal kepada konsumen dan membuat variabel Corporate design menjadi variabel yang paling dominan di dalam penelitian ini. Komponen lain dari Corporate design adalah desain interior yang salah satunya meliputi tata letak rak di dalam gerai. Indikator "Saya tertarik dengan desain interior gerai Alfamart (pencahayaan, tata letak rak, dll)" mendapatkan scoring ratarata sebesar 3.49. Tata letak rak yang mampu membantu konsumen dalam menemukan barang yang dicari merupakan nilai lebih yang dimiliki oleh gerai Alfamart ini. Sebagian responden berbelanja di Alfamart sebanyak 2-3 kali dalam seminggu, sehingga penataan rak yang baik akan memudahkan konsumen dalam menemukan barang yang mereka cari.

Hasil ini didukung oleh penelitian yang dilakukan oleh Fathoni (2013) yang menyebutkan bahwa corporate design berpengaruh dominan terhadap ekuitas merek. Hasil penelitian Danibrata (2011) juga menyebutkan bahwa corporate design berpengaruh signifikan terhadap ekuitas merek, hanya saja hasilnya tidak dominan. 


\section{KESIMPULAN}

Penelitian ini memiliki tujuh dimensi, dimana ada tiga dimensi yang berpengaruh signifikan terhadap ekuitas merek Alfamart dan empat dimensi yang tidak berpengaruh signifikan terhadap ekuitas merek Alfamart. Dimensi tersebut dijelaskan sebagai berikut :

1. Iklan Tidak Berpengaruh Terhadap Ekuitas Merek Alfamart

2. Promosi Penjualan Berpengaruh Terhadap Ekuitas Merek Alfamart

3. Penjualan Personal Berpengaruh Terhadap Ekuitas Merek Alfamart

4. Hubungan Masyarakat Tidak Berpengaruh Terhadap Ekuitas Merek Alfamart

5. Pemasaran Langsung Tidak Berpengaruh Terhadap Ekuitas Merek Alfamart

6. Pemasaran Interaktif Tidak Berpengaruh Terhadap Ekuitas Merek Alfamart

7. Corporate Design Berpengaruh Terhadap Ekuitas Merek Alfamart

\section{Implikasi Teoritis}

Implikasi teoritis berisi tentang kontribusi yang diperoleh dari penelitian terhadap teori yang ada. Implikasi yang diharapkan pada peneliitan ini adalah sebagai berikut:

1. Dimensi Corporate design menjadi dimensi yang paling dominan dalam penelitian ini dengan nilai koefisien regresi b 0.297. Hasil ini sama dengan penelitian yang dilakukan Fathoni (2013), dimana dalam penelitian tersebut Corporate design merupakan variabel yang berpengaruh secara dominan.

2. Penelitian ini serupa dengan penelitian yang dilakukan oleh Fathoni (2013). Hanya saja, di dalam penelitian ini dimensi yang berpengaruh terhadap ekuitas merek adalah dimensi promosi penjualan, penjualan personal, dan Corporate design. Sedangkan di dalam penelitian yang dilakukan oleh Fathoni (2013), variabel yang berpengaruh terhadap ekuitas merek adalah promosi penjualan, penjualan personal, Corporate design, dan pemasaran interaktif.

\section{Implikasi Terapan}

Berdasarkan hasil analisis dan pembahasan maka implikasi terapan yang dapat diharapkan dari penelitian ini adalah sebagai berikut:

1. Alfamart perlu meningkatkan lagi mengenai iklan yang dibuat, karena selama ini iklan Alfamart belum begitu menarik perhatian bagi konsumen danjuga indikator "iklan Alfamart membuat saya tertarik untuk berbelanja" memperoleh skor rata-rata paling rendah. Alfamart harus mengevaluasi pemasangan iklan di website public, karena pembaca merasa terganggu dengan hal tersebut.

2. Alfamart sudah memiliki beberapa event CSR yang sudah dibuat, tetapi eventevent tersebut belum merata di tiap gerai yang mereka miliki. Sehingga akan lebih baik jika di setiap gerai juga melakukan program-program CSR secara kecilkecilan, atau bisa dilakukan di setiap kota dimana terdapat gerai Alfamart.

3. Alfamart perlu lebih gencar lagi membagikan katalog belanja yang mereka punya, sehingga informasi mengenai Alfamart bisa lebih tersebar tidak hanya di dalam gerai. Hal ini terlihat pada indikator "Alfamart secara rutin membagikan katalog belanja" memperoleh skor rata-rata yang paling rendah.

4. Alfamart perlu lebih mengiklankan website yang mereka miliki kepada konsumen, sehingga konsumen bisa lebih lagi memanfaatkan website Alfamart. Hal ini terlihat pada indikator "saya sering mencari informasi mengenai promosi di website" yang memperoleh nilai rata-rata paling rendah.

\section{DAFTAR PUSTAKA}

Bachdar, S. (2015). Siapa Penguasa Ritel di Indonesia?http://marketeers. com/article/siapa-penguasa-ritel-diindonesia.html. Diunduh tanggal 12 Februari 2016.

Belch, George E., Belch, Michael A. (2009). Advertising and Promotion : An IntegratedMarketing Communication 
Perpective. 8th Edition. New York : McGraw-Hill.

Cutlip, Scott M. Allen H. Center \& Glen M. Broom. (2006). Effective Public Relations. New Jersey: Prentice Hall.

Danibrata, Aulia. (2011). Pengaruh Integrated Marketing Communication Terhadap Brand Equity Pada Sebuah Bank Pemerintah di Jakarta. Jurnal Bisnis dan Akuntansi Vol. 13, No 1. Jakarta: STIE Trisakti

Durianto, Darmadi. Sugiarto \& Tony Simanjuntak. (2004). Strategi Menaklukan Pasar Melalui Riset Ekuitas dan Perilaku Merek. Jakarta: Gramedia Pustaka Utama

Fathoni, Fathir, dkk. (2013). Pengaruh Komunikasi Pemasaran Terpadu Terhadap Ekuitas Merek. Jurnal Administrasi Bisnis Vol. 4, No 2. Malang: Universitas Brawijaya.

Fill, Chris. (2009). Marketing Communication - Interactivity, Communities, and Content 5th ed. New Jersey: Prentice Hall.

http://ekbis.sindonews.com/read/1007773/34/ pertumbuhanritel-indonesia-peringkat12-dunia-1433163799.Diunduh tanggal 25 Juni 2015.

h t t p : / / r a d a r p e n a c c o m / $\mathrm{read} / 2015 / 03 / 31 / 17425 / 18 / 1 / \% 20$ Aprindo-Perkirakan-PertumbuhanIndustri-Retail-12. Diunduh tanggal 9 Juli 2015.

Kartikasari, N.P. (2014). Pengaruh Komunikasi Pemasaran Terpadu Terhadap Ekuitas Merek. Jurnal Interaksi Vol. 3, No 2. Semarang: Universitas Diponegoro.

Kotler P. dan G. Amstrong. (2008). PrinsipPrinsip Pemasaran Edisi 12 Jilid 2. Jakarta: Erlangga

Kotler dan Keller, (2009).Marketing Management Edisi 13, Global Edition. Pearson Prentice Hall.
Kotler dan Keller, (2014).Marketing Management Edisi 15, Global Edition. Pearson Prentice Hall.

Lovelock, Christopher, dkk. (2010). Pemasaran Jasa, Manusia, Teknologi, Strategi. Jakarta: Penerbit Erlangga

Morissan. (2010). Periklanan: Komunikasi Pemasaran Terpadu. Edisi 1. Jakarta. Kencana Prenadamedia Group.

Peter, J.Paul, James H.Donnelly, Jr. (2011). A Preface To Marketing Management. Twelfth Edition. New York: Mc Graw Hill.

Prayitno, Sunarto. (2010). Analisis Dampak Implementasi Strategi Komunikasi Pemasaran Terpadu dalam PenciptaanEkuitas Merek. Journal of Strategic CommunicationVol. 1, No 1. Jakarta: Universitas Pancasila

Reedy, Joel, Shauna Schullo, Kenneth Zimmerman. (2000). Electronic Marketing-Integrating Electronic Resourdes into the Marketing Process. Orlando: The Dryden Press

Shimp, T.A. (2010), Advertising, promotion , \& other aspects of Integrated Marketing Communication, 8th Edition, SouthWestern, CengageLearning.

Suwantara N, Taechamaneesatit T. (2012). The Forms of Integrated Marketing Communication that Effect the Brand Equity Perception in Direct Sale System Comparing Thai and Foreign Cosmetics Brand.International Proceedings of Economics Development \& Research.

Suyanto. (2007). Marketing Strategy Top Brand Indonesia. Andi, Yogyakarta.

www.bps.go.id. Diunduh tanggal 5 Februari 2016. 